\title{
Acid fog and hospital visits for asthma: an epidemiological study
}

\author{
H. Tanaka*, S. Honma*, M. Nishi**, T. Igarashi+, S. Teramoto*, F. Nishio ${ }^{++}$, S. Abe*
}

Acid fog and hospital visits for asthma: an epidemiological study. H. Tanaka, S. Honma, M. Nishi, T. Igarashi, S. Teramoto, F. Nishio, S. Abe. CERS Journals Ltd 1998.

ABSTRACT: The aim of this study was to elucidate the adverse respiratory effects of naturally occurring acid fog.

In total, 102 adult asthmatic patients (44 nonatopic and 58 atopic) were studied for a 2 yr period (January 1992 to December 1993) in Kushiro, a city with only a small industrial area, located in the northern-most island in Japan. Fog occurred on 378 out of 731 days, and the acidity of the fog ranged from $\mathrm{pH} 3.32$ to 6.91 (mean pH 4.95). The association between hospital visits for asthma and meteorological factors or air pollutants was investigated. In nonatopic patients, fog, high ozone and water vapour pressure, low day-to-day temperature differences, low concentrations of atmospheric $\mathrm{NO}$ and $\mathrm{NO}_{2}$ contributed significantly $(p<0.05)$ to increasing hospital visits. In atopic subjects, fog, high water vapour pressure, low levels of atmospheric $\mathrm{NO}_{2}$ and $\mathrm{SO}_{2}$ contributed significantly to hospital visits $(\mathbf{p}<0.05)$. In Poisson regression analysis the remaining factors of significance $(p<0.01)$ for nonatopic asthma were fog and low NO and for atopic asthma were high water vapour pressure and low $\mathrm{SO}_{2}(\mathrm{p}<0.05)$. A weak but significant correlation was observed between the number of hospital visits and the mean $\mathrm{pH}$ of the foggy day $(\mathrm{r}=-\mathbf{0 . 3 8}, \mathrm{p}<0.05)$ in nonatopic asthmatic patients, not in atopic asthma. On foggy days, gaseous air pollutant levels were significantly $(p<0.01)$ lower than on fog-free days.

It was concluded that, naturally occurring acid fog may have a weak bronchoconstrictive effect which appears to be more influential in nonatopic asthmatic subjects than in atopic subjects.

Eur Respir J 1998; 11: 1301-1306.
*Third Dept of Internal Medicine, Sapporo Medical University School of Medicine, Sapporo, Japan. **Public Health, Sapporo Medical University School of Medicine, Sapporo, Japan. +Respiratory Medicine, Kushiro City General Hospital, Kushiro, Japan. ${ }^{++}$Hokkaido University of Education, Kushiro, Japan.

Correspondence: H. Tanaka

Third Dept of Internal Medicine

Sapporo Medical University School of Medicine

South-1, West-16

Chuo-ku, Sapporo 060-8543

Japan

Fax: 81116131543

Keywords: Acid fog

air pollutant

asthma

weather factor

Received: July 71997

Accepted after revision December 271997
Acid fog contains multiple stimuli that may have an adverse effect on human airways. Fog water has been shown to scavenge and concentrate airborne pollutants and to imbue respirable particles with compounds potentially injurious to the bronchial epithelium. Naturally occurring fog has recently been shown to be quite acidic, with $\mathrm{pH}$ values as low as 1.7 [1]. In Kushiro, a city with only a small industrial area, located in north-eastern Japan, where floating fog from the Pacific Ocean frequently occurs every summer, the annual average $\mathrm{pH}$ of fog in 1991 was 4.91 and the minimum was 3.39. It was recently reported that hospital visits for asthma increased on foggy days in $8.8 \%$ of the adult asthmatics in Kushiro [2]. Historical air pollution disasters with high mortality and morbidity have occurred during periods of fog [3]. The health consequences of acid fog have provoked significant concern in the light of results which reveal that fog water may contain substantial concentrations of strong acid [4]. Acid fog is associated with air pollutants including nitrogen oxides $\left(\mathrm{NO}_{\mathrm{x}}\right)$, sulphur dioxides $\left(\mathrm{SO}_{2}\right)$ and ozone $\left(\mathrm{O}_{3}\right)$, and most fog acidity is attributable to sulphuric acid $\left(\mathrm{H}_{2} \mathrm{SO}_{4}\right)$ and nitric acid $\left(\mathrm{HNO}_{3}\right)$.

Exposure to acidic aerosols and sulphates has been associated with increased respiratory mortality, morbidity and symptoms in a variety of settings [5-7]. Controlledexposure chamber studies suggest that asthma patients may be more sensitive than normal volunteers to the negative respiratory effects of acidic aerosols [8-10]. The effects of exposure to ambient acid aerosol on asthmatic symptoms have been studied epidemiologically [11-13], but there have been no reports investigating the effects on nonatopic or atopic asthmatic patients.

In the Harvard Six Cities Study, chronic coughs and bronchitis were more closely correlated with hydrogen ion $\left(\mathrm{H}^{+}\right)$concentration than with particle concentration [14]. Recently, DoCKERY et al. [15] reported that children living in communities with the highest level of strongly acidic particles were more likely to report bronchitis than children living in the least polluted communities. Daily ambient concentrations of $\mathrm{H}^{+}$in Denver, USA were associated with reports of moderate or severe coughs and shortness of breath in a large panel of adult asthmatics [11]. KoENIG et al. [8] reported that acidic pollutants increased airway resistance in asthmatics. Therefore, in order to test this hy-pothesis, the influence of acidity in the fog on airways in asthmatic patients was investigated.

The purpose of this study was to elucidate the respiratory effects of naturally occurring acid fog on adult nonatopic and atopic asthmatics. The results of the association between ambient acid fog and daily hospital visits are reported, including hospitalization, emergency room and outpatient visits for asthma symptoms obtained by medical 
records, and compared with the effects of other meteorological variables and gaseous air pollutants in Kushiro city during a 2 yr period from 1992 to 1993.

\section{Materials and methods}

\section{Subjects}

All subjects were recruited from Kushiro City General Hospital and gave their informed consent. Of 257 asthmatic patients who visited the hospital, 182 subjects were residents of Kushiro city and medical records were obtained for 102 of these 182 subjects from January 1992 to December 1993. The subjects (15-79 yrs old) were 45 males and 57 females. A previous report on the same subjects has been published [2]. The characteristics of the patients are shown in table 1. The diagnosis of asthma was defined as a history of recurrent episodes of wheezing, chest tightness and Š20\% variability in forced expiratory volume in one second (FEV1) on a week-to-week basis, confirmed by a chest physician. Nine patients were severe, 53 were moderate and 40 were mild asthmatics according to the following definition [16]: severe (frequent exacerbations and FEV1 $660 \%$ pred); moderate (daily symptoms and FEV1 $>60-<80 \%$ pred); and mild (symptoms Sonce per week but ðonce per day and FEV1 S $80 \%$ pred). Forty patients were treated with oral theophylline and inhaled salbutamol, 62 patients received inhaled beclomethasone dipropionate (300-1200 $\mu \mathrm{g} \cdot$ day $\left.^{-1}\right)$ and eight cases received oral prednisolone. Nonatopic asthmatics were defined by a negative skin-prick test for common aeroallergens (aqueous extracts of house dust, mite, mugwort and cat), a total serum immunoglobulin-E (IgE) concentration within the normal range $\left(0-100 \mathrm{IU} \cdot \mathrm{mL}^{-1}\right)$ and no positive antigenspecific serum IgE tested by the commercial kit (MAST systems, Hitachi Kasei, Tokyo, Japan). The MAST system includes 16 antigens (house dust, mite, ragweed, orchard grass and two other grasses, Japanese cedar, Alternaria and four other moulds, cat, dog, egg and soybean). When patients had at least one of the following criteria they were defined as atopic: 1) one or more positive skin-prick tests; 2) a total serum IgE level of more than $500 \mathrm{IU} \cdot \mathrm{mL}^{-1}$; or 3 ) one or more positive antigen-specific serum IgE. On the

Table 1. - Characteristics of patients

\begin{tabular}{|c|c|c|c|}
\hline & $\begin{array}{l}\text { Nonatopic } \\
\quad(n=44)\end{array}$ & $\begin{array}{l}\text { Atopic } \\
(n=58)\end{array}$ & $\mathrm{p}$-value \\
\hline$\overline{\text { Gender } \mathrm{M} / \mathrm{F}}$ & $12 / 32$ & $33 / 25$ & $<0.01$ \\
\hline Age yrs* & $52 \pm 16(21-79)$ & $41 \pm 16(15-70)$ & $<0.01$ \\
\hline Eosinophils $^{+}$ & $386 \pm 51$ & $488 \pm 61$ & NS \\
\hline $\begin{array}{l}\text { Total serum } \\
\mathrm{IgE}^{+} \mathrm{IU} \cdot \mathrm{mL}-1\end{array}$ & $43 \pm 28$ & $876 \pm 100$ & $<0.0001$ \\
\hline $\begin{array}{l}\text { Severity of asthma } \\
\text { Mild/moderate/ } \\
\text { severe }\end{array}$ & $16 / 24 / 4$ & $24 / 29 / 5$ & NS \\
\hline $\mathrm{BDP}+/-$ & $18 / 26$ & $22 / 36$ & NS \\
\hline ð400 $\mu \mathrm{g} \cdot$ day $^{-1} \mathrm{n}$ & 12 & 23 & NS \\
\hline$>400 \mu \mathrm{g} \cdot$ day $^{-1} \mathrm{n}$ & 14 & 13 & \\
\hline PSL p.o. & 4 & 4 & NS \\
\hline
\end{tabular}

$>5 \mathrm{mg} \cdot$ day $^{-1} \mathrm{n}$

$\because$ : asthma severity was defined in reference [16]; *: mean \pm SD (range); +: mean \pm SD. M: male; F: female; IgE: immunoglobulinE; BDP: beclomethasone dipropionate; PSL: prednisolone; Ns: nonsignificant. basis of these criteria. Forty four patients were nonatopic and 58 patients were considered to be atopic. There were significant differences between atopic and nonatopic subjects in sex and age, but there were no significant differences in blood eosinophil count, asthma severity and medication (table 1). Individual hospital visits for asthma were noted retrospectively from the patients' medical records. The number of visits was counted as follows. If the same patient visited for 2 or more consecutive days due to one asthma exacerbation, this was counted as one visit. Any visit within 2 weeks after the acute exacerbation were not counted. To obtain information on personal exposure to the fog, the questionnaire asked each participant to answer "yes" or "no" as to whether they refrained from going outside the house during the duration of the fog.

\section{Meteorological data}

The following daily meteorological data were collected from the Kushiro Meteorological Observatories: fog occurrence and duration, barometric pressure, temperature, water vapour pressure, relative humidity, wind velocity and wind direction. Fog was defined as an atmospheric state existing when normal horizontal vision was reduced to less than $1.0 \mathrm{~km}$. Fog water was sampled using a screen collector in which droplets were collected by inertial impaction, and the acidity of the fog water was measured immediately with a $\mathrm{pH}$ meter (Toadenpakougyou, Tokyo, Japan). Daily data regarding the $24 \mathrm{~h}$ average on air pollutants, suspended particulate matter (SPM) of less than $10 \mu \mathrm{m}, \mathrm{SO}_{2}$, nitrogen oxide (NO), nitrogen dioxide $\left(\mathrm{NO}_{2}\right)$, $\mathrm{NO}_{\mathrm{x}}$ and ozone, were obtained from the department of Health and Environment, Hokkaido Prefecture.

\section{Statistical analysis}

The descriptive factors of age, eosinophil count and serum IgE level are given as mean \pm SD. Unpaired t-tests, Chisquared tests, and post hoc tests were performed for these background factors, and air pollutants or meteorological factors were measured to compare between foggy days and fog-free days. The cut-off values were mean \pm SD for each of the air pollutant and meteorological factors (see table 3 ). Odds ratios (OR) and $95 \%$ confidence intervals $(95 \% \mathrm{CI})$ of hospital visits were calculated based on these values [17]. For example, the presence of fog (+) has a 2.5-fold higher risk than that of no fog (-). Poisson regression analysis was performed for the same dichotomized air pollutants and meteorological factors [18]. Pearson's correlation was used to assess the relation among air pollutants and meteorological factors, and the correlation between the number of hospital visits and the mean fog $\mathrm{pH}$ of that day. Values of pð0.05 were considered statistically significant.

\section{Results}

Fog occurred on 378 out of 731 days, and fog acidity ranged from $\mathrm{pH} 3.32-6.91$ (mean $\mathrm{pH} 4.95$ ). The duration of fog and number of individual foggy days were as follows: $<3 \mathrm{~h}, 229$ days; $>3 \mathrm{~h}$ and $<6 \mathrm{~h}, 62$ days; $>6 \mathrm{~h}$ and $<9$ 
Table 2. - Air pollutants and meteorological factors on foggy and fog-free days

\begin{tabular}{|c|c|c|c|}
\hline & $\begin{array}{c}\text { Foggy day } \\
\mathrm{n}=378\end{array}$ & $\begin{array}{c}\text { Fog-free } \\
\mathrm{n}=353\end{array}$ & p-value \\
\hline NO ppb & $5.9 \pm 4.8$ & $7.8 \pm 6.1$ & $<0.001$ \\
\hline $\mathrm{NO}_{2} \mathrm{ppb}$ & $9.2 \pm 4.6$ & $11.5 \pm 5.7$ & $<0.001$ \\
\hline $\mathrm{SO}_{2} \mathrm{ppb}$ & $3.2 \pm 2.4$ & $3.7 \pm 1.9$ & $<0.01$ \\
\hline $\mathrm{SPM} \mu \mathrm{g} \cdot \mathrm{m}^{-3}$ & $23.2 \pm 13.0$ & $24.8 \pm 12.4$ & NS \\
\hline $\mathrm{O}_{3} \mathrm{ppb}$ & $19.2 \pm 9.9$ & $21.4 \pm 8.4$ & $<0.01$ \\
\hline Barometric pressure $\mathrm{hPa}$ & $1006 \pm 7$ & $1010 \pm 7$ & $<0.001$ \\
\hline $\begin{array}{l}\text { Daily temperature difference }{ }^{\circ} \mathrm{C} \\
\text { (max minus min) }\end{array}$ & $5.5 \pm 6.4$ & $8.6 \pm 3.3$ & $<0.001$ \\
\hline $\begin{array}{l}\text { Day-to-day temperature difference }{ }^{\circ} \mathrm{C} \\
\text { (max of previous day minus min) }\end{array}$ & $6.1 \pm 5.4$ & $9.0 \pm 3.3$ & $<0.001$ \\
\hline Water vapour pressure $\mathrm{hPa}$ & $11.3 \pm 4.4$ & $5.3 \pm 3.2$ & $<0.001$ \\
\hline Relative humidity (mean) \% & $86.6 \pm 8.6$ & $68.3 \pm 10.9$ & $<0.001$ \\
\hline Relative humidity (minimum) $\%$ & $70.5 \pm 15.3$ & $49.0 \pm 12.8$ & $<0.001$ \\
\hline Wind velocity (mean) $\mathrm{m} \cdot \mathrm{min}^{-1}$ & $3.3 \pm 1.3$ & $3.6 \pm 1.4$ & $<0.001$ \\
\hline Wind velocity (maximum) $\mathrm{m} \cdot \mathrm{min}^{-1}$ & $6.7 \pm 2.4$ & $7.0 \pm 2.2$ & NS \\
\hline Wind direction (south) at maximal velocity $\%$ & 59.4 & 34.6 & $<0.001$ \\
\hline
\end{tabular}

ppb: parts per billion; SPM: suspended particulate matter; ss: nonsignificant.
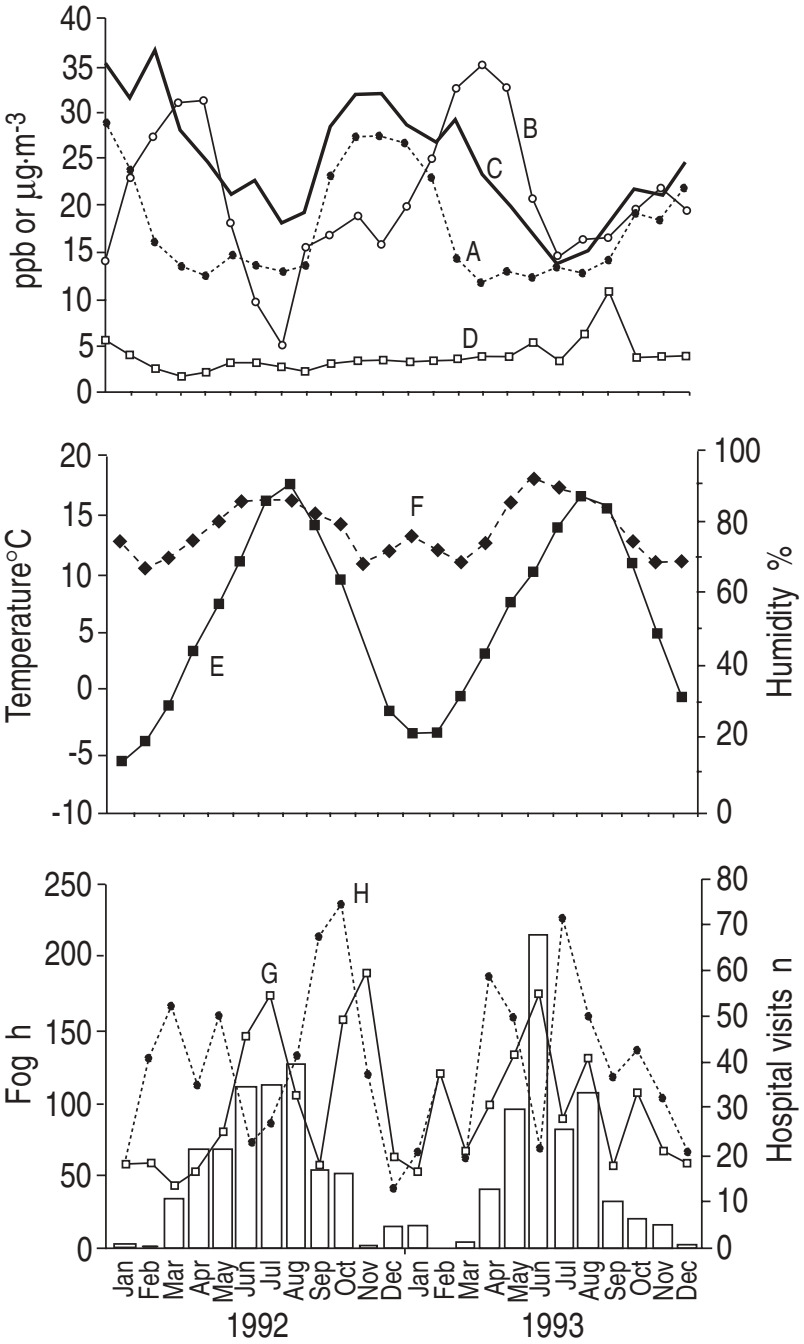

Fig. 1. - Monthly mean values of air pollutants, climatic factors, duration of fog and respiratory hospital visits from January 1992 to December 1993. Nitrogen oxides (A), ozone (B) and sulphur dioxides (D) are presented as parts per billion (ppb), and suspended particulate matter of less than $10 \mu \mathrm{m}(\mathrm{C})$ is expressed as $\mu \mathrm{g} \cdot \mathrm{m}^{-3}$. E: Monthly mean temperature; F: relative humidity; and number of hospital visits for asthma in nonatopic $(\mathrm{G})$ and atopic $(\mathrm{H})$ asthmatics. h, 36 days; and $>9$ h, 51 days. The differences in air pollutants and meteorological variables between foggy days and fog-free days are shown in table 2. $\mathrm{NO}, \mathrm{NO}_{2}, \mathrm{SO}_{2}$ and ozone on the foggy days were significantly $(\mathrm{p}<0.01)$ lower than on the fog-free days. Daily temperature difference, day-to-day temperature difference and mean wind velocity on foggy days were significantly $(\mathrm{p}<0.001)$ lower than those on fog-free days. Water vapour pressure, relative humidity (mean and minimum) and per cent of southerly (ocean direction) wind on foggy days were significantly $(p<0.001)$ higher than on fog-free days. The time-course of air pollutants, temperature, relative humidity, hospital visits of asthmatic patients, and fog duration in the period from January 1992 to December 1993 are shown in figure 1. Over $100 \mathrm{~h}$ of fog per month was observed in June, July and August 1992 and in June and August 1993. The mean $\mathrm{pH}$ of fog during the $2 \mathrm{yr}$ was 4.95 (range 3.32-6.91). The number of nonatopic asthma exacerbation cases had three peaks, in July and November 1992 and June 1993, two of which coincided with the foggy season. In atopic asthma attack cases there were three peaks, in October 1992, April and July 1993.

Pearson's correlation coefficients between air pollutants and meteorological factors on the 731 days were calculated. $\mathrm{NO}_{\mathrm{x}}$ was correlated with SPM $(\mathrm{r}=0.70, \mathrm{p}<0.001)$ and ozone was negatively correlated with water vapour pressure $(\mathrm{r}=-0.44, \mathrm{p}<0.001)$. Water vapour pressure was correlated with temperature $(\mathrm{r}=0.94, \mathrm{p}<0.001)$ and relative humidity $(\mathrm{r}=0.64, \mathrm{p}<0.001)$.

The number of hospital visits for asthma was 706 for nonatopic asthmatic subjects and 546 for atopic asthmatic patients during this survey. In the nonatopic patients NO, $\mathrm{NO}_{2}$, SPM, and day-to-day temperature differences showed significantly decreased OR. Fog and water vapour pressure, in contrast, showed significantly increased OR (table 3). Since these factors interact with one another, they were used to perform a Poisson regression analysis (table 4). Day-to-day temperature differences and water vapour pre-ssure revealed no significant difference, indicating that they contributed not to the increase in asthmatic attacks, but to the development of fog. In this multiple regression analysis low concentrations of NO and the existence of fog remained significant, i.e. NO 
Table 3. - Odds ratio of hospital visits and 95\% confidence intervals for air pollutants and meteorological variables

\begin{tabular}{|c|c|c|c|c|}
\hline \multirow[b]{2}{*}{ Air pollutant and meteorological parameter } & \multicolumn{2}{|c|}{ Nonatopic patients } & \multicolumn{2}{|c|}{ Atopic patients } \\
\hline & $\mathrm{OR}$ & $(95 \% \mathrm{CI})$ & OR & $(95 \% \mathrm{CI})$ \\
\hline NO Š10 vs $<10 \mathrm{ppb}$ & 0.52 & $(0.40-0.68)$ & 0.87 & $(0.74-1.02)$ \\
\hline NO Ś 15 vs $<15 \mathrm{ppb}$ & 0.62 & $(0.45-0.84)$ & 0.81 & $(0.67-0.97)$ \\
\hline $\mathrm{SO}, \breve{\mathrm{S}}_{5} v \mathrm{~s}<5 \mathrm{ppb}$ & 1.18 & $(0.96-1.46)$ & 0.78 & $(0.66-0.93)$ \\
\hline 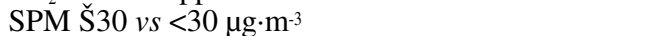 & 0.77 & $(0.61-0.98)$ & 0.87 & $(0.75-1.02)$ \\
\hline $\mathrm{O}_{3} \mathrm{~S} 25 v s<25 \mathrm{ppb}$ & 1.27 & $(1.04-1.55)$ & 0.99 & $(0.86-1.14)$ \\
\hline Fog yes $v s$ no & 2.50 & $(1.26-4.93)$ & 1.66 & $(1.09-2.51)$ \\
\hline Barometric pressure Š1000 vs $<1000 \mathrm{hPa}$ & 0.65 & $(0.30-1.40)$ & 1.78 & $(0.89-3.53)$ \\
\hline Daily temperature difference $\mathrm{S} 10 v s<10^{\circ} \mathrm{C}$ & 0.53 & $(0.22-1.30)$ & 0.86 & $(0.52-1.41)$ \\
\hline Day-to-day temperature difference Š10 vs $<10^{\circ} \mathrm{C}$ & 0.40 & $(0.16-0.96)$ & 0.78 & $(0.48-1.25)$ \\
\hline Water vapour pressure S $12 v s<12 \mathrm{hPa}$ & 1.87 & $(1.02-3.43)$ & 1.54 & $(1.00-2.37)$ \\
\hline Relative humidity (mean) Š 90 vs $<90 \%$ & 1.14 & $(0.58-2.24)$ & 1.24 & $(0.78-1.96)$ \\
\hline Relative humidity (minimum) Š $75 v s<75 \%$ & 1.15 & $(0.82-2.88)$ & 0.83 & $(0.52-1.34)$ \\
\hline Wind velocity (mean) $\mathrm{S} 4 \mathrm{vs}<4 \mathrm{~m} \cdot \mathrm{min}^{-1}$ & 0.64 & $(0.31-1.34)$ & 0.77 & $(0.48-1.24)$ \\
\hline Wind velocity (maximum) $\mathrm{S} 9 v s<9 \mathrm{~m} \cdot \mathrm{min}^{-1}$ & 0.78 & $(0.35-1.73)$ & 0.66 & $(0.38-1.16)$ \\
\hline Wind direction at maximal velocity south $v s$ others & 1.09 & $(0.59-1.99)$ & 1.33 & $(0.88-1.99)$ \\
\hline
\end{tabular}

OR: odds ratio; CI: confidence interval; ppb: parts per billion; SPM: suspended particulate matter.

Table 4. - Results of Poisson regression analysis

\begin{tabular}{|c|c|c|c|c|c|c|c|c|}
\hline & $\begin{array}{c}\mathrm{NO} \\
\text { Š10 ppb }\end{array}$ & $\begin{array}{c}\mathrm{NO}_{2} \\
\text { S } 15 \mathrm{ppb}\end{array}$ & $\begin{array}{c}\mathrm{SO}_{2} \\
>5 \mathrm{ppb}\end{array}$ & $\begin{array}{c}\text { SPM } \\
\text { SP } 30 \mu \mathrm{g} \cdot \mathrm{m}^{-3}\end{array}$ & $\begin{array}{c}\mathrm{O}_{3} \\
\check{\mathrm{S}} 25 \mathrm{ppb}\end{array}$ & $\begin{array}{l}\text { Fog } \\
\text { yes }\end{array}$ & $\begin{array}{l}\text { Temp. } \\
\text { Š } 10^{\circ} \mathrm{C}\end{array}$ & $\begin{array}{l}\text { Vapour press. } \\
\mathrm{S} 12 \mathrm{hPa}\end{array}$ \\
\hline \multicolumn{9}{|l|}{ Nonatopic } \\
\hline Coefficient estimate & $-0.52 * *$ & 0.21 & -0.09 & -0.01 & 0.16 & $-0.33 * *$ & -0.14 & -0.04 \\
\hline Standard error & 0.17 & 0.22 & 0.11 & 0.15 & 0.12 & 0.10 & 0.13 & -0.11 \\
\hline \multicolumn{9}{|l|}{ Atopic } \\
\hline Coefficient estimate & 0.08 & -0.15 & $-0.24 *$ & -0.002 & 0.12 & 0.04 & 0.04 & $0.19 *$ \\
\hline Standard error & 0.01 & 0.14 & 0.09 & 0.09 & 0.08 & 0.07 & 0.08 & 0.09 \\
\hline
\end{tabular}

ppb: parts per billion; Temp.: day-to-day temperature difference; Vapour press.: water vapour pressure; SPM: suspended particulate matter. $*$ : $\mathrm{p}<0.05 ; * *: \mathrm{p}<0.01$.

absorbed in fog particles increases the risk of asthmatic attack. An apparent concentration of NO becomes low after its absorption by fog. In the group of atopic patients, although low $\mathrm{SO}_{2}$, low $\mathrm{NO}_{2}$, high water vapour pressure and the existence of fog showed significantly $(\mathrm{p}<0.05)$ increased OR (table 3), the Poisson regression analysis (table 4) suggested that the contribution of air pollutants absorbed by fog was not as great as in nonatopic patients, since the coefficient value of the fog existence was not significant.

Pearson's correlations between the number of hospital visits and the mean fog $\mathrm{pH}$ of the day were performed separately in atopic and nonatopic asthma. There was a significant inverse correlation in nonatopic asthmatics ( $\mathrm{r}=$ $0.38, \mathrm{p}<0.05$ ), as visits would increase on low $\mathrm{pH}$ foggy days. However, no such correlation was found in atopic asthmatics ( $\mathrm{r}=-0.19$, nonsignificant).

The questionnaire demonstrated that six out of 44 patients from the nonatopic and nine out of 57 atopic subjects refrained from going out during foggy periods. There was no significant difference $(\mathrm{p}=0.98)$ between the two groups.

\section{Discussion}

In this study, fog had the highest positive value of all the measured meteorological variables and air pollutants in nonatopic asthma, and a significant correlation between the number of visits and fog $\mathrm{pH}$ was also found. These results suggest that the inhalation of naturally occurring acid fog might have adverse respiratory effects, especially on nonatopic asthma. To our knowledge, this is the first published study to compare the respiratory effects of naturally occurring acid fog on nonatopic and atopic adult asthmatics. McManus et al. [19] reported that nonallergic asthmatics are more sensitive to short-term, low-level $\mathrm{SO}_{2}$ exposure than are healthy, age-matched control subjects. As nonallergic asthma was more responsive than allergic asthma to ipratropium bromide [20], nonallergic asthmatics may have increased resting parasympathetic tone. It was estimated that $\mathrm{H}^{+}$air pollutants would produce bronchospasm as a result of postsynaptic muscarinic receptor stimulation. However, the magnitude of this response was highly variable between individual subjects in groups of both nonallergic and allergic asthmatics $[20,21]$.

The results revealed that hospital visits by nonatopic asthma patients increased on days with low levels of NO and those by atopic subjects increased on low $\mathrm{SO}_{2}$ days. This observation is inconsistent with most air pollution epidemiology as high levels of air pollutants have conventionally been linked with asthma exacerbation [22]. The levels of atmospheric $\mathrm{NO}$ and $\mathrm{SO}_{2}$ on foggy days decreased in comparison with fog-free days. In this study, the level of these air pollutants was measured in the gaseous phase, excluding fog water. Gaseous air pollutants may be scavenged and concentrate themselves in fog water. Therefore, the levels of $\mathrm{NO}$ and $\mathrm{SO}_{2}$ in the ambient air may be low and these compounds, including $\mathrm{H}^{+}$, might be concentrated in fog water, which could decrease the $\mathrm{pH}$ levels. Therefore, the fact that hospital visits increased on foggy days with low levels of air pollution might be due to 
the scavenging of air pollutants by the fog. Many possible mechanisms of oxidative injury have been associated with $\mathrm{HNO}_{3}, \mathrm{H}_{2} \mathrm{SO}_{4}$ and $\mathrm{O}_{3}$, and $\mathrm{H}^{+}$itself might have adverse effects on the bronchial epithelium. Increased airway resistance caused by acidic pollutants may have been due to the reduced buffer or $\mathrm{H}^{+}$ion absorption capacity of the airway mucus, which is mainly a function of high molecular weight mucous proteins, especially glycoproteins [23]. The normal $\mathrm{pH}$ of the fluid lining human airways ranges from 6.5-7.5, with a mean value of about 6.9 [23], or 6.6 [24]. Intracellular and intercellular oedema begins to occur at approximately $\mathrm{pH} 6.5$ in the mucosa of cow trachea, and below $\mathrm{pH} 6$ the epithelium loosens itself from the basement membrane [25]. London air pollution data from 1958-1972, including daily measurements of smog, $\mathrm{SO}_{2}$ and aerosol acidity, showed aerosol acidity to be more predictive of daily mortality than either smog of $\mathrm{SO}_{2}$ [6]. Ontario, Canada and New York, USA have also shown levels of atmospheric acidity or sulphate that correlate with rates of hospital admission for acute respiratory disease during the summer months when acid hazes occur [26]. In contrast, some reports suggested that daily mortality was associated with particulate matter but not with aerosol acidity [27].

The limitation of this study is that the use of outdoor fog-monitoring data to estimate personal exposure introduces error into the exposure assessment. QUAKENBOSs et al. [28] reported an indoor:outdoor ratio of 0.5 for particulate matter under $10 \mu \mathrm{m}$ in the homes of nonsmokers in Tucson, Arizona. Dockery and SPengler [29] reported an indoor:outdoor ratio of 0.55 for total suspended particulates in Steubenville, Ohio. In general, the diameter of fog droplets is in the order of 10-15 nm [30], and therefore fog particles may be capable of floating indoors.

Hospital visits by nonatopic patients increased on low $\mathrm{pH}$ foggy days, but the relation was weak. Neutralization of strong acid fog with endogeneous ammonia may reduce the effects of the inhaled acid aerosol. The results of the reaction of ammonia with the acid aerosol suggested that inhaled aerosol might be neutralized inside the airways or outside in the breathing zone [31]. However, CLARK et al. [32] reported that endogenous ammonia did not effectively prevent the inhalation of ambient acid, but might neutralize approximately one-quarter of inhalable acid in healthy volunteers.

In this study fog occurred under conditions of low barometric pressure, with minimum differences in temperature and a weak coastal wind. High water vapour pressure and high relative humidity seemed to occur as a result of the fog. The level of water vapour pressure was positively correlated with hospital visits by atopic patients. Relatively high humidity may often have a favourable effect on airways, but it may also facilitate the production of fungal spores, which might be a cause of allergic reactions in atopic subjects. In the Six-City Study of schoolchildren, indoor dampness was strongly associated with lung dysfunction, and could result in more fungal spores indoors $[33,34]$.

In Kushiro city, dense fogs occurred on about half of the total number of foggy days. The diameter of the fog droplets was not measured. In general, fog droplets can have a median diameter in the order of 10-15 $\mu \mathrm{m}$ [30], and mean droplet diameter may range from $>10 \mu \mathrm{m}$ in dense fog to $<1 \mu \mathrm{m}$ during relatively low humidity. In this study droplets of $10 \mu \mathrm{m}$ or larger in diameter might constitute a large part of the total number. LinN et al. [35] mentioned that such droplet size (i.e. fog) tended to exacerbate short-term symptomatic respiratory responses. Aerosols of a mean aerodynamic diameter of $1 \mu \mathrm{m}$ or less have received the most attention in health studies because they are typical of acidic ambient pollution and are respirable into the deep lung.

The present results showed a trend towards an increase in hospital visits for asthma during periods of fog. The foggy seasons occurred during the late spring and throughout the summer in Kushiro, whereas respiratory exacerbation of adult asthma occurred more frequently in the spring and autumn in Japan [36]. Therefore, the trend of hospital visits in this study might be attributable to the foggy conditions in Kushiro and not to seasonal variations in Japan. Not all peaks of hospital visits in nonatopic patients could be explained by the fog. The reason for the second peak in 1992 could not be elucidated, but the common colds that were prevalent during this period may have been a trigger factor.

In conclusion, hospital visits for asthma exacerbation in nonatopic asthmatic patients were found to increase on foggy days, especially on days with lower $\mathrm{pH}$ fog. Because levels of gaseous air pollutants on foggy days were lower than those on fog-free days, air pollutants may have been absorbed by the fog and the acidity of fog water may then be increased. Naturally occurring acid fog may have a weak bronchoconstrictive effect, which appears to be more influential in nonatopic asthmatic patients than in atopic subjects.

\section{References}

1. Jacob DJ, Waldman JW, Munger JW, Hoffman MR. Chemical composition of fog water collected along the California coast. Environ Sci Technol 1985; 19: 730735 .

2. Tanaka H, Honma S, Nishi M, Igarashi T, Nishio F, Abe S. Two-year follow-up study of the effect of acid fog on adult asthma patients. Internal Med 1996; 35: 100-104.

3. Goldman JM. Effects of air Pollution on human health. In: Stern AC, ed. Air pollution. 2nd Edn. Vol. 1. New York, Academic Press, 1968; pp. 547-615.

4. Waldman JM, Munger JW, Jacob DJ, Flagan RC, Morgan JJ, Hoffman MR. Chemical composition of acid fog. Science 1982; 218: 677-680.

5. Balmes JR, Fine JM, Gordon T, Sheppard D. Potential bronchoconstrictor stimuli in acid fog. Environ Health Perspect 1989; 79: 163-166.

6. Thurston GD, Ito K, Lippmann M, Hayes C. Re-examination of London, England, mortality in relation to exposure to acidic aerosols during 1963-1971 winters. Environ Health Perspect 1989; 79: 73-82.

7. Bates DV, Sizto R. The Ontario air pollution study: identification of the causative agent. Environ Health Perspect 1989; 79: 69-72.

8. Koenig JQ, Pierson WE, Horike M. The effect of inhaled sulfuric acid on pulmonary function in adolescent asthmatics. Am Rev Respir Dis 1983; 128: 221-225.

9. Utell MJ. Effect of inhaled acid aerosols on lung mechanics: analysis of human exposure studies. Environ Health Perspect 1985; 63: 39-44. 
10. Avol EL, Linn WS, Wightman LH, Whynot JD, Anderson KR, Hackney JD. Short term respiratory effects of sulfuric acid in fog: a laboratory study of healthy and asthmatic volunteers. J Air Pollut Control Assoc 1988; 38: $258-263$.

11. Ostro BD, Lipset MJ, Wiener MB, Selner JC. Asthmatic response to airborne acid aerosols. Am J Public Health 1991; 81: 694-702.

12. Pope Ca, Kalkstein LS. Synoptic weather modeling and estimates of the exposure-response relationship between daily mortality and particulate air pollution. Environ Health Perspect 1996; 104: 414-420.

13. Kalkstein LS. Health and climate change-direct impacts in cities. Lancet 1993; 342: 1397-1399.

14. Speizer FE. Studies of acid aerosols in six cities and in a new multicity investigation: design issues. Environ Health Perspect 1989; 79: 61-67.

15. Dockery DW, Cunningham J, Damokosh AI, et al. Health effects of acid aerosols on North American children: respiratory symptoms. Environ Health Perspect 1996; 104: 500-505.

16. Global Initiative for Asthma. Diagnosis and classification. Global strategy for asthma management and prevention NHLBI/WHO workshop report. NIH Publication No. 95-3659, 1995; 47-61.

17. Mantel N, Haenzel W. Statistical aspects of the analysis of data from retrospective studies of disease. J Natl Cancer Inst 1959; 22: 719-748.

18. Frome EL, Checkoway H. Epidemiologic programs for computers and calculators. Use of Poisson regression methods in estimating incidence rate and ratios. Am J Epidemiol 1985; 121: 309-323.

19. McManus MS, Koenig JQ, Altman LC, Pierson WE. Pulmonary effects of sulfur dioxide exposure and ipratropium bromide pretreatment in adults with nonallergic asthma. J Allergy Clin Immunol 1989; 83: 619-626.

20. Ruffin RE, McIntyre E, Crockett AJ, Zeilonka K, Alpers $\mathrm{JH}$. Combination bronchodilator therapy in asthma. J Allergy Clin Immunol 1982; 69: 60-65.

21. Horstman D, Roger LJ, Kehrl H, Hazucha M. Airway sensitivity of asthmatics to sulfur dioxide. Toxicol Ind Health 1986; 2: 289-298.

22. Ware JH, Ferris BG Jr, Dockery DW, Spengler JD, Stram DD, Speizer FE. Effects of ambient sulfur oxides and suspended particles on respiratory health of pre-adolescent children. Am Rev Respir Dis 1986; 133: 834-842.
23. Guerrin F, Voisin C, Macquet KV, Robin H, Lequien P. Application of measuring bronchial $\mathrm{pH}$ in situ. Prog Respir Res 1971; 6: 373-383.

24. Bodem CR, Lampton LM, Miller DP, Tarka EF, Everett DE. Endobronchial pH. Relevance to aminoglycoside activity in gram-negative bacillary pneumonia. Am Rev Respir Dis 1983; 127: 39-41.

25. Holma B, Lindegren M, Andrson MJ. pH effects on ciliomotility and morphology of respiratory mucosa. Arch Environ Health 1977; 32: 216-226.

26. Thurston GD, Ito K, Hayes CG, Bates DV, Lippman M. Respiratory hospital admissions and summertime haze air pollution in Toronto, Ontario: consideration of the role of acid aerosols. Environ Res 1994; 65: 271-290.

27. Dockery DW, Schwartz J, Spengler JD. Air pollution and daily mortality associations with particulates and acid aerosols. Environ Res 1992; 59: 362-373.

28. Quackenboss JJ, Lebowitz MD, Crutchfield CD. Indoor-outdoor relationship for particulate matter: exposure classifications and health effects. Environ Int 1989; 15: 353-360.

29. Dockery DW, Spengler JD. Indoor-outdoor relationships of respirable sulfates and particles. Atm Environ 1982; 15 : 335-343.

30. Deal WJ. The quantity of acid fog. J Air Pollut Cont Assoc 1983; 33: 691-692.

31. Larson TV. The influence of chemical and physical forms of ambient air acids on airways dose. Environ Health Perspect 1989; 79: 7-13.

32. Clark KW, Anderson KR, Linn WS, Gong H Jr. Influence of breathing-zone ammonia on human exposures to acid aerosol pollution. J Air Waste Manage Assoc 1995; 45: 923-925.

33. Brunekreef B, Dockery D, Speizer F, Ware J, Spengler J, Ferris B. Home dampness and respiratory morbidity in children. Am Rev Respir Dis 1989; 140: 1363-1367.

34. Williamson IJ, Martin CJ, McGill G, Monie RDH, Fennerty AG. Damp housing and asthma: a case-control study. Thorax 1997; 52: 229-234.

35. Linn WS, Avol EL, Anderson KR, Shamoo DA, Peng R, Hackney JD. Effect of droplet size on respiratory responses to inhaled sulfuric acid in normal and asthmatic volunteers. Am Rev Respir Dis 1989; 140: 161-166.

36. Akiyama K. Research Group on Adult Bronchial Asthma and Respiratory Failure. Adult bronchial asthma in Japan. Jpn J Thoracic Dis 1991; 29: 984-991. 